Chirurgia (2020) 115: 643-649

No. 5, September - October

Copyright@ Celsius

http://dx.doi.org/10.21614/chirurgia.115.5.643

\title{
Treatment of Children Hemangiomas
}

\author{
Elena Țarcă \\ "Grigore T. Popa” University of Medicine and Pharmacy, Faculty of Medicine, Department of Surgery (II), Iași, Romania \\ Pediatric Surgery Department, "Saint Mary” Emergency Children Hospital, Iași, Romania
}

Corresponding author:

Elena Țarcă, MD, PhD

Assistant Professor, Pediatric surgeon

Pediatric Surgery Department

"Saint Mary" Emergency Children

Hospital, lași, Romania

Vasile Lupu Street, No. 62-64

E-mail: elatarca@gmail.com
Received: 10.05 .2020

Accepted: 05.07.2020

\section{Rezumat}

Tratamentul hemangioamelor la copil

Introducere: Hemangioamele sunt cele mai frecvente tumori benigne ale copilului, creşterea necontrolată în dimensiuni a tumorii putând provoca complicații grave, ce necesită tratament în centre specializate. În ciuda frecvenței lor ridicate şi a posibilelor complicații, în prezent nu există un consens privind tratamentul optim. Strategia poate varia de la simpla observație până la implicarea mai multor specialități medicale, radiologice şi chirurgicale, care necesită tratament farmacologic şi chirurgical.

Scop: Studiul actual analizează rezultatele tratamentului hemangioamelor efectuat într-un spital terțiar din România, pentru a putea ulterior compara datele cu cele din literatura de actualitate recentă.

Metodă:În studiul nostru retrospectiv am analizat datele a 142 de pacienți tratați în spitalul nostru, în secția de chirurgie pediatrică, pentru o perioadă de aproximativ 2 ani. Au fost analizate statistic datele demografice, localizarea hemangioamelor, durata spitalizării şi tratamentului, şi complicațiile.

Rezultate: Am obtinut rezultate favorabile în peste $80-90 \%$ din cazuri prin combinarea tratamentului cu propranolol per os cu injectiii intralezionale cu bleomicină, aplicarea topică a timololului şi excizia chirurgicală; managementul terapeutic a fost stabilit în funcție de localizarea şi complexitatea hemangiomului şi de vârsta pacientului.

Concluzii: Scopul tratamentului în cazul hemangioamelor la copil este acela de a stopa din timp creşterea tumorii, şi în acelaşi timp de a asigura pacientului şi familiei o evoluție favorabilă. Un asemenea deziderat poate fi atins prin administrarea concomitentă sau secvențială a mai multor metode terapeutice, care să acționeze în timpul fazei proliferative a celulelor tumorale. 
Cuvinte cheie: copil, hemangiom, propranolol, bleomicină, timolol

\begin{abstract}
Introduction: Hemangiomas are the most common benign tumors in infancy and the uncontrolled increase in size can cause serious complications, requiring treatment in specialized centers. Despite their high frequency and possible complications, there is currently no consensus on optimal treatment. The strategy may vary from simple observation to the involvement of several medical, radiological and surgical specialties, requiring both pharmacological and surgical treatment. Aim: The current study analyzes the results of the treatment of hemangiomas performed in a tertiary hospital in Romania, in order to compare the data with those in the recent literature.

Methods: In our retrospective study we analyzed the data of 142 patients treated in our tertiary hospital for a period of approximately 2 years. Demographics, localization of hemangiomas, duration of hospitalization and treatment, and complications were statistically analyzed.

Results: We achieved favourable outcomes in over $80-90 \%$ of cases by combining propranolol treatment with bleomycin injections, topical application of timolol and surgical excision, depending on the location and complexity of the hemangioma, and the age of the patient.

Conclusions: The goal of hemangioma therapy is to stop hemangioma growth in its tracks, and has to provide relief and reassurance to patients and families. Such therapies might consist of combinations of drugs given concurrently or perhaps sequentially to target cells that are most active in the proliferating phase.
\end{abstract}

Key words: children, hemangioma, propranolol, bleomycin, timolol

\section{Introduction}

Infantile hemangiomas are benign vascular tumors of endothelial cells, being the most benign tumor in infancy, with an incidence that varies from $4 \%$ to $10 \%$ of infants (1). Incriminated risk factors are female gender (female/male ratio 3/1), low birth weight, multiple pregnancies, prematurity, advanced maternal age, white race, and in vitro fertilization. Hemangiomas are well-known for its rapid growth during the first weeks to months of a child's life followed by stagnation and spontaneous but slow involution (2). Approximately $50 \%$ of the hemangiomas regress spontaneously until the age of 5 years and $90 \%$ regress completely by the age of 9 (3). Although benign tumors, the uncontrolled increase in hemangiomas size can cause serious complications, functional and cosmetic problems such as ulceration and infection, bleeding, disfigurement of the area to which they belong, obstruction of upper airways or vision, congestive heart failure, consumption coagulopathy and, in rare cases, death. Approximately $12 \%$ of hemangiomas are thought to be complex, requiring treatment in specialized centers (4). The areas most commonly affected are head and cervical region. Although most of the hemangiomas are unique, $20 \%$ of the children have three or more skin hemangiomas, which require extensive investigations to detect any visceral hemangiomas. Hepatic hemangiomas, but also intestinal, splenic, intracranial, renal, pulmonary, ocular, etc., can be most frequently diagnosed.

The current study analyzes the results of the treatment of hemangiomas performed in a tertiary hospital in Romania, in order to compare the data with those in the recent literature. 


\section{Material and Methods}

We conducted a retrospective analytical study on 149 children hospitalized and treated in the Pediatric Surgery Department of a tertiary hospital for a period of approximately 2 years (January 2015 - September 2016). The patients were identified according to the disease code entered in the hospital's computerized database, and then the patients' records were extracted from the hospital archives. A number of 149 patients were identified, of whom 7 patients were excluded from the study for missing dates. Demographics, localization of hemangiomas, type, duration of hospitalization and treatment, and complications were statistically analyzed for those 142 patients with complete files. The data were processed using the specialized Microsoft Excel data analysis and processing module. This study was approved by the ethics committee of the hospital and the publication of the photos was done with the written consent of the parents.

In terms of treatment, $10 \mathrm{mg}$ propranolol hydrochloride tablets were used, which were divided into the hospital pharmacy at appropriate doses of $2 \mathrm{mg} / \mathrm{kg} /$ day, divided into three low-powdered powders, mixed in a small amount of tea or milk and administered on the mouth. As a sclerosing agent bleomycin medac was used in doses ranging from 0.3 to $2 \mathrm{mg}$ per injection, depending on the age of the child and the size of the hemangioma. The injection was performed under general anesthesia, in the radial manner, until the hemangioma became pale. The interval of injection was around 4 weeks, with total times between 5 and 10 times during therapeutic period. For topical applications ophthalmic drops with $0.5 \%$ timolol solution, applied twice daily for a minimum of 3 months, were used. For surgical excision as the first therapeutic option, patients with relatively small size hemangiomas, located in less visible areas, or patients who, for demographic, socio-economic or medical reasons, were not eligible for another form of treatment, have been selected. Surgical excision was also used in combination with the other methods of treatment for complex hemangiomas, as well as for residual lesions, scar, hypertrophy, or pigmentation.

\section{Results}

Data were analyzed for 142 patients, 101 of whom were female $(71.2 \%)$ and 41 were male $(28.8 \%)$, with a ratio female/male of $2.5 / 1$. Patients were aged between 1 day and 15 years. The reasons for presenting to the physician consisted, for 83 patients (96.5\%), in the presence or subsequent appearance, in the following weeks after birth, of a reddishraspberry tumor which increased in size, the growth rate of the tumor exceeding the child's growth rate. As localization, 49 children (56.9\%) had hemangioma in the head (face or scalp), 25 children $(29.0 \%)$ in the chest or abdomen, 19 children $(22.0 \%)$ in upper or lower limbs, 7 (8.1\%) perineal and 22 children (25.5\%) had multiple hemangiomas. Of the other three patients, one had oral mucosal hemangioma, another one at the tongue, and a 3 year-old girl was accidentally diagnosed with an abdominal ultrasound with hepatic hemangioma. From those 142 patients, 64 were treated only with propranolol, 16 were treated only with bleomycin, 25 hemangiomas were excised from the beginning, 7 patients received no treatment, 2 patients received only topical application of timolol, and 28 patients received a combination of above mentioned methods (Fig. 1A,B).

For the 64 patients treated with propranolol alone the mean age was 5.7 months, with a median age of 4 month (two patients over the age of 3 years, ie a child of 3.5 years and a child of 9 years, were excluded from the calculation of the arithmetic mean of the age in order not to misinterpret the average to the right). Patients with higher age were selected for Bleomycin, ie the mean age was 4 years and 2 months. The group of patients undergoing surgical excision was the most inhomogeneous, aged between 2 months and 15 years, with a mean age of 3.5 years. For patients who did not receive treatment during the study, being only investigated, with the exception of a newborn of 23 days, the mean age was 8 years and 7 months. 

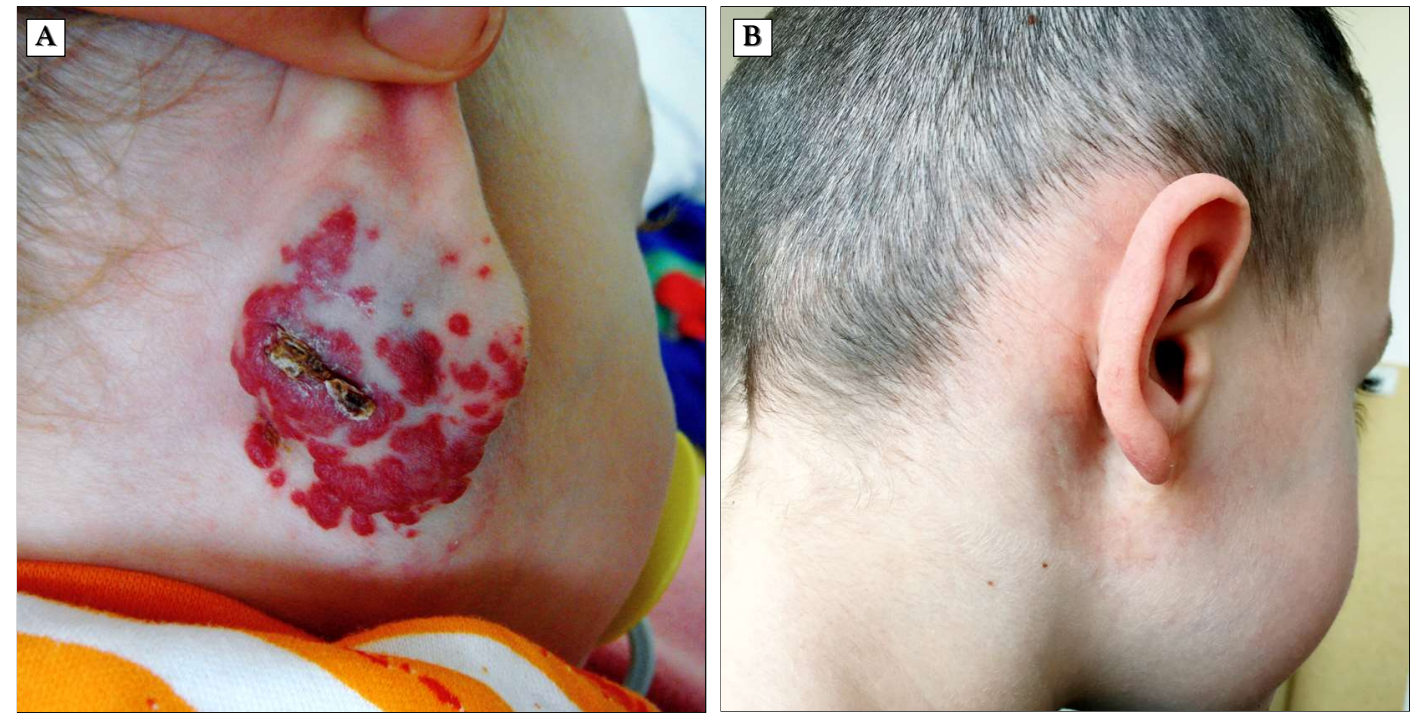

Figure 1. (A) 4-month-old ulcerated retro auricular haemangioma at the onset of propranolol and intralesional injections of bleomycin; (B) at the age of 5 years

Regarding treatment, 64 children were treated only with propranolol at a dose of 1 $\mathrm{mg} / \mathrm{kg} / \mathrm{day}$, divided into three intakes as powders, for 2 days, and subsequently with a dose increase of $2 \mathrm{mg} / \mathrm{kg} /$ day, in three outlets. On the day of initiation of treatment as well as at increasing the dose of propranolol, patients were monitored for blood glucose, blood pressure and pulse rate without significant changes in any patient. In a patient, propranolol was not given anymore after the first dose due to the mother's refusal to continue treatment. Patients were discharged on average after 4 days, followed by a monthly return to control for clinico-paraclinical assessment and dose adjustment based on weight. On average, treatment with propranolol lasted 5 months in patients receiving concomitant bleomycin and 7 months in those who received propranolol alone. Of the 64 patients treated exclusively with propranolol, the progression was favorable in 60 of them (93.7\%) (Fig. 2A, B), three patients had no significant improvement and one gave up the treatment; we calculated a failure rate of propranolol treatment of $4.6 \%$. There was no serious adverse event to report.

In the group of patient treated with bleomycin injections only, evolution was good in 14 of 16 cases $(87.5 \%)$. Two patients treated with bleomycin injections developed ulcerations in the hemangioma and then developed unsightly scars.

In the group of 25 patients whose surgical excision was the first treatment line, the evolution was favorable in 22 cases (88\%). A hemangioma recurred probably because it was not entirely excised, a patient developed postoperative hematoma and subsequently unaesthetic scar, and another patient developed an operative wound infection that required drainage and antibiotherapy.

The mean age of the patient group treated by several methods was 1 year and 3 months (between 3 days and 11 years); this group included 28 patients with complex hemangioma, resistant to a single treatment method, recurrent hemangiomas, or patients who needed plastic surgery (Fig. $3 \mathrm{~A}, \mathrm{~B}, \mathrm{C}$ ). In 18 patients, propranolol was administered concomitantly with the initiation of intralesional injections of bleomycin, performed at one month intervals, under general anesthesia, at doses ranging from $0.3-2 \mathrm{mg} /$ injection, depending on the age of the child and the size hemangioma. Evolution was favorable in 16 of 18 patients $(88.8 \%)$ who were treated with bleomycin and propranolol (Fig. $1 \mathrm{~A}, \mathrm{~B}$ ); the other two were treated with hemangioma 

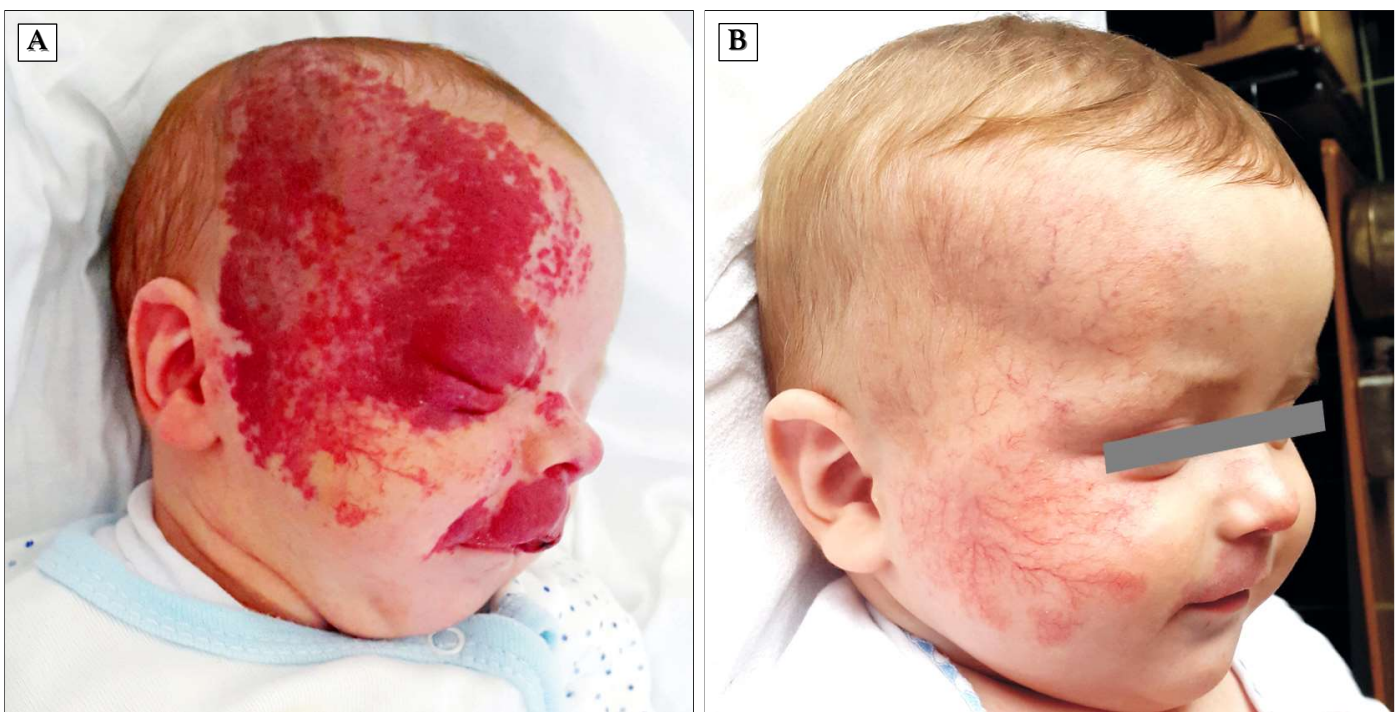

Figure 2. (A) Hemangioma in the baby for 1.5 months at the start of propranolol treatment; (B) after 4 months of propranolol treatment

excision after three months of conservative treatment and no significant improvement. Of this group included 10 children with multiple hemangiomas who have been treated with combined methods (bleomycin injection, propranolol by mouth, surgical excision and/or and timolol applications), with a favorable evolution in 9 out of 10 cases (90\%).

The two patients who were treated only with local timolol applications, aged 9 and 11 months, respectively, had a favorable evolution, with diminishing the colour and thickness of the hemangioma located at the genian level in both cases.

\section{Discussions}

Gender distribution, demographic data, age of occurrence and location of hemangiomas analyzed in our study confirm, in general, data from the literature $(1,4,5)$. We have found a female/male ratio of $2.5 / 1$, comparing with ratio ranging from $3 / 1$ to $5 / 1$ in the literature (5). Hemangioma can occur in any region of the body, but the most is commonly found in the head and neck region (60\%), followed by the trunk (25\%) and then by extremities (15\%) (5), and in comparison we have found a prevalence of $56.9 \%$ in the head, $29.0 \%$ in the chest or abdomen and $22.0 \%$ in upper or lower

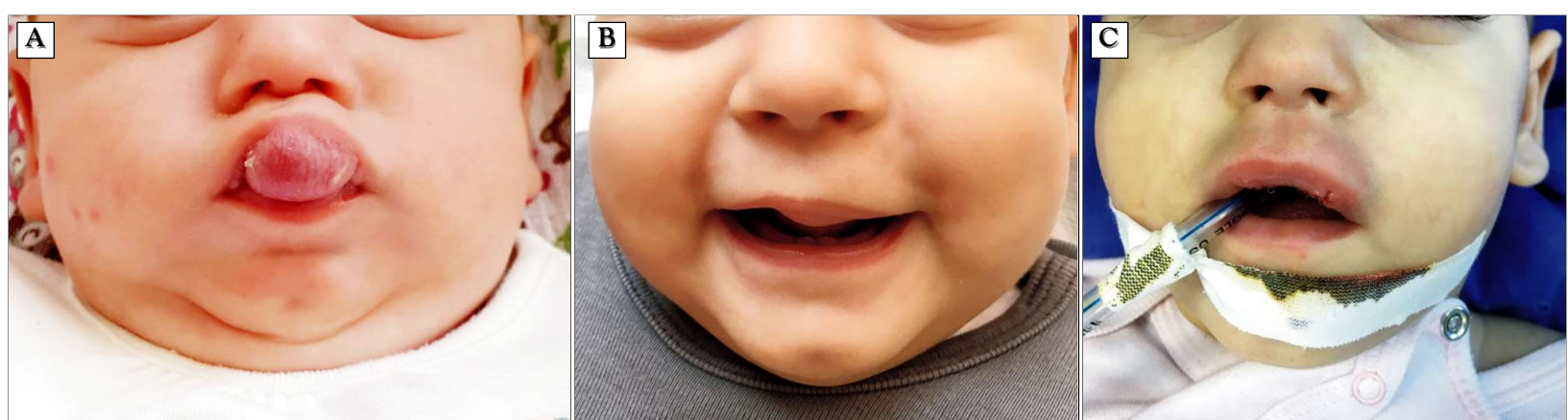

Figure 3. (A) Upper lip hemangioma in a 2 month old infant; (B) after 6 month of propranolol treatment; (C) after redundant skin excision 
limbs. Despite the high frequency of hemangiomas in children and possible complications, and also because the possibility of spontaneous regression, there is currently no consensus on optimal treatment. Many physicians recommend careful supervision of the patient without any active treatment, in the hope of spontaneous regression of the lesion, but this approach is dangerous because there may be psychological problems related to aesthetics, problems such as low self-confidence, a negative image of physical appearance, and distress of the child and the parents (6) Therefore, the treatment strategy may vary from simple observation to the involvement of several medical, radiological and surgical specialties, requiring both pharmacological and surgical treatment, depending on the hemangioma's cell growth stage. The type, location and stage of evolution of hemangioma, extent and number of lesions, systemic involvement, presence of local complications, psychological impairment, and the desire of parents will be taken into account. In general, impairment of any function (ocular, auricular, aerial, genito-urinary, locomotive) or cosmetic appearance (localization on the nose, labia or hemangiomas that disfigures the cranio-facial region) or ulcerated hemangiomas require urgent treatment. In our study we achieved favorable outcomes in over $80-90 \%$ of cases, depending on the complexity of the hemangioma, the age of the patient and the treatment chosen. Pharmacological treatment involves the administration of interferon alpha, corticosteroids, vincrisine, cyclophosphamide, bleomycin, and since 2008, propranolol is increasingly used $(7,8)$. Despite its widespread use, propranolol's mechanism of action remains uncertain, also the results are very good. Some of the proposed mechanisms include vasoconstriction, decreased renin production, inhibition of angiogenesis, and stimulation of apoptosis (9).

Induction of a rapid involution of the lesion and lack of side effects compared to steroid therapy make propranolol the first line of treatment for complex hemangiomas (10). Recently, a consensus was reached regarding the treatment of hemangiomas in children, respectively the administration of propranolol orally, in a total dose of $2 \mathrm{mg} / \mathrm{kg}$ and per day, divided into 2 or 3 doses, for 6-8 months (8). In our clinic we have followed these recommendations and propranolol has become the preferred treatment method for hemangiomas over the last 10 years. A comprehensive review of the literature showed that in publications with adequate data from which to calculate age at initiation of therapy, the mean age was 5.1 months, with a median age of 4 months (8). In our study we calculated a similar starting age for propranolol treatment of 5.7 month, with a median age of 4 month. It seems that early start of propranolol therapy results in better outcomes, so it is always better to start the treatment as early as possible during rapid proliferation of the tumor (11). The same extensive study previously mentioned found a failure rate of propranolol treatment of $1.6 \%$, much lower than in our study (4.6\%). The small rate may be underestimated because treatment failures may not be as commonly reported (8).

When the results with propranolol treatment are not good enough, we resort to bleomycin injections. We have achieved very good results with injections of bleomycin as sclerosing agent to modulate angiogenesis of the infantile haemangiomas, and even better when using bleomycin in combination with propranolol. As side effects, we only recorded two cases of hemangioma ulceration with subsequent vicious cicatrisation. Other side effects cited in the literature are post-injection edema, gastrointestinal disorders, pulmonary fibrosis (12). Some studies report favorable results after bleomycin injections concomitantly with prednisone administration by mouth (12), but we have little experience in the treatment of hemangiomas with prednisone. There are also studies that report a favorable evolution after intralesional injection of triamcinolone acetate, but our experience with this drug is limited (13).

Surgical excision is applicable as the first treatment method only in some carefully selected cases, in combination with other 
methods in complex cases, or as treatment of residual lesions (14). Surgery may involve excision, laser therapy, and for difficult cases such as hepatic hemangiomas, embolization, robotic surgery and even transplantation or radiotherapy (15). Also, cases with favorable development are reported under topical applications with $0.5 \%$ timolol maleate for superficial cutaneous hemangiomas, which are not ulcerated and do not involve mucous membranes (16). We have used timolol solution only in two cases, with favourable outcome. There are few studies in the literature that report good results with these therapy, and timolol $0.5 \%$ may be a promising topical alternative for small superficial infantile haemangiomas, but additional studies are warranted (17).

\section{Conclusions}

The goal of hemangioma therapy is to stop hemangioma growth in its tracks, and has to provide relief and reassurance to patients and families. Such therapies might consist of combinations of drugs given concurrently or perhaps sequentially to target cells that are most active in the proliferating phase.

\section{Conflict of Interest}

There is no conflict of interest.

\section{References}

1. Hoornweg MJ, Smeulders M J, Ubbink DT, van der Horst CM. The prevalence and risk factors of infantile haemangiomas: a casecontrol study in the Dutch population. Paediatr Perinat Epidemiol. 2012;26(2):156-62. Epub 2011 Sep 20.
2. Greenberger $\mathrm{S}$, Bischoff J. Pathogenesis of infantile haemangioma. Br J Dermatol 2013;169(1):12-9.

3. Donnelly LF, Adams DM, Bisset GS 3rd. Vascular malformations and hemangiomas: A practical approach in a multidisciplinary clinic. AJR Am J Roentgenol. 2000;174(3):597-608.

4. Haggstrom AN, Drolet BA, Baselga E, Sarah L Chamlin, Garzon MC, Horii KA, et al. Prospective study of infantile hemangiomas: clinical characteristics predicting complications and treatment. Pediatrics. 2006;118(3):882-7.

5. Zheng JW, Zhang L, Zhou Q, Mai HM, Wang YA, Fan XD et al. A practical guide to treatment of infantile hemangiomas of the head and neck. Int J Clin Exp Med. 2013;6(10):851-60.

6. Tarcă E, Gavrilescu S, Ciomaga IM, Criscov I, Rosu TS, Savu B. Infantil hemangioma - therapeutic approaching Possibilities. Pediatru.ro. 2018;50(2). DOI: 10.26416/Pedi.50.2.2018.1769.

7. Léauté-Labrèze $\mathrm{C}$, Dumas de la Roque $\mathrm{E}$, Hubiche $\mathrm{T}$, Boralevi $\mathrm{F}$, Thambo JB, Taïeb A. Propranolol for severe hemangiomas of infancy. N Engl J Med 2008;358(24):2649-51.

8. Beth A. Drolet, Peter C. Frommelt, Sarah L. Chamlin, Anita Haggstrom, Nancy M. Bauman, Yvonne E. Chiu, et al. Initiation and Use of Propranolol for Infantile Hemangioma: Report of a Consensus Conference. Pediatrics 2013 January; 131(1):128-40.

9. Chim H, Armijo BS, Miller E, Gliniak C, Serret MA, Gosain AK. Propranolol induces regression of hemangioma cells through HIF1a-mediated inhibition of VEGF-A. Ann Surg 2012;256(1):146-56.

10. Tarcă E, Cojocaru E, Roșu ST, Butnariu LI, Plămădeală P, Moisă ȘM. Differential diagnosis difficulties related to infantile hemangioma - case report and literature review. Rom J Morphol Embryol. 2019;60(4):1375-9.

11. Jing Ge, Jiawei Zheng, Ling Zhang, Weien Yuan, Haiguang Zhao. Oral propranolol combined with topical timolol for compound infantile hemangiomas: a retrospective study. Sci Rep. 2016; 6:19765.

12. Luo Q-f, Zhao F-y. The effects of Bleomycin A5 on infantile maxillofacial haemangioma. Head Face Med. 2011;7:11.

13. Wang W-y, Wang L-h, Huang G, Lin Z-y, Lin H. Intralesional injection of triamcinolone acetonide for cavernous hemangiomas: A case report. Medicine (Baltimore). 2019;98(37):e16986.

14. Barrón-Peña A, Martínez-Borras MA, Benítez-Cárdenas 0, PozosGuillén A, Garrocho-Rangel A. Management of the oral hemangiomas in infants and children: Scoping review. Med Oral Patol Oral Cir Bucal. 2020;25(2):e252-e261.

15. Minggen Hu, Kuang Chen, Xuan Zhang, Chenggang Li, Dongda Song, Rong Liu. Robotic, laparoscopic or open hemihepatectomy for giant liver haemangiomas over $10 \mathrm{~cm}$ in diameter. BMC Surg. 2020;20(1):93.

16. Chan H, McKay C, Adams S, Wargon 0 . RCT of timolol maleate gel for superficial infantile hemangiomas in 5 - to 24-week-olds. Pediatrics 2013;131(6):e1739-47.

17. Chu MB, Searcy G, Siegfried E. Efficacy of topical brimonidinetimolol for haemangioma of infancy and perils of off-label prescribing. BMJ Case Rep. 2013;2013:bcr2013009365. 